\title{
Radiological Impact Assessment of Mining on Soil, Water and Plant Samples from Okobo Coal Field, Nigeria
}

\author{
A. U. Itodo ${ }^{1 *}$, P. O. Edimeh ${ }^{1,2}$, I. S. Eneji ${ }^{1}$, R. A. Wuana ${ }^{1}$ \\ ${ }^{1}$ Department of Chemistry and Centre for Agrochemical Technology \& Environmental Research (CATER), Federal University of \\ Agriculture, Makurdi, Nigeria \\ ${ }^{2}$ Department of Medical Laboratory Technology, College of Health Science and Technology, Idah Kogi State, Nigeria \\ Email: ^itodoson2002@gmail.com
}

How to cite this paper: Itodo, A. U., Edimeh, P. O., Eneji, I. S., \& Wuana, R. A. (2020). Radiological Impact Assessment of Mining on Soil, Water and Plant Samples from Okobo Coal Field, Nigeria. Journal of Geoscience and Environment Protection, 8, 65-81. https://doi.org/10.4236/gep.2020.85005

Received: March 12, 2020

Accepted: May 12, 2020

Published: May 15, 2020

Copyright (c) 2020 by author(s) and Scientific Research Publishing Inc. This work is licensed under the Creative Commons Attribution International License (CC BY 4.0).

http://creativecommons.org/licenses/by/4.0/

\begin{abstract}
Anthropogenic, including mining activities leaves the environment contaminated with potentially toxic substances and remote hazards if not properly checked. The quest in this study is the levels of naturally occurring radionuclides in Okobo coal, Nigeria and their possible distribution in coal mine vicinity soils, water and plants (cassava). Samples were characterized for levels of radionuclides and radiological detriments using high resolution gamma spectrometer, Gamma ray liquid scintillation and applicable radiological hazard indices. The range of mean activity concentrations $\left(\mathrm{Bq} \cdot \mathrm{kg}^{-1}\right)$ for the environmental samples are as follows: ${ }^{226} \mathrm{Ra}(8.39 \pm 1.0$ to $77.6 \pm 4.0),{ }^{232} \mathrm{Th}(0.470 \pm 0.4$ and $77.8 \pm 2)$, and ${ }^{40} \mathrm{~K}(29.1 \pm 0.4$ and $289 \pm 6)$, with their respective mean values of $32.7 \pm 2.1,54.0 \pm 1.5$ and $158.8 \pm 3.1\left(\mathrm{~Bq} \cdot \mathrm{kg}^{-1}\right)$. Radiological detriments including radium equivalent activity $\left(R a_{e q}\right)$, external hazard index $\left(H_{e x}\right)$, internal hazard index $\left(H_{i n}\right)$, radioactivity level index or gamma index $\left(I_{\gamma}\right)$ and the ELCR for coal sample is $96.94 \mathrm{~Bq} \cdot \mathrm{kg}^{-1}, 0.26,0.30,0.69$, and 1.56 respectively. Reported values were below the safety limits stipulated by UNSCEAR and implied that the environment is relatively safe with low levels of natural radioactivity. Overall, this background study has demonstrated that Okobo coal mine is a less radio-hazard contributor to environmental samples. Exceptions to this generalization are representative gamma index $\left(I_{\gamma r}\right)$ and annual effective dose equivalent values for some cassava and soil samples, which may call for future impact monitoring.
\end{abstract}

\section{Keywords}

Coal, Radiological Detriments, Hazard, Okobo, Activity Concentrations Gamma-Ray Spectrometry 


\section{Introduction}

In spite of its abundant deposits in Nigeria, Coal does not presently contribute to Nigeria's electricity generation. The problem with mining activities in Nigeria is the negligence of the stakeholders (miners, businessmen and the government) to provide best global mining practices.

The unsuspected populace that constitute these communities where coal mining activities take place, do not know their environmental obligations under the minerals and mining act. This affects their rights including right to education, infrastructures, life, security, health, adequate standard of living, liberty (Sambo et al., 2012).

Threats, linked to the residual and temporal side effects of coal mining on the environmental and agricultural dimensions are well documented (Bergh et al., 2011; Odunayo et al., 2016). There are strong indications of coal's impact on human health and the environment. Air pollution generated by coal mining and combustion in power plants (Din et al., 2013) can affect the environment and human health. Key pollutants from coal mining of adverse impacts on the environment and health include oxides of $\mathrm{C}, \mathrm{S}$, and $\mathrm{N}$. Others include particulate matter, heavy metals (Ikwuagwu, 2017) and organic pollutants (PAHs, PCBs among others) even at low concentration pollute the environment.

Coal mining impact on groundwater quantity and quality, as it also impacts on river flows and consequential impact on agricultural land uses cannot be overemphasized (Ikwuagwu, 2017). Environmental impacts for coal mining range from mining subsidence, changes in ground water regimes and mining hydrology. There is also the release of methane into the atmosphere, the release of contaminated water and the generation of solid waste products.

Naturally occurring radionuclides are reported in varying proportions in rocks and soil of several geo-formations, including coal mine. These radionuclides may be deposited in sediment and dissolve into drinking water, thereby leading to human exposure (Raymond et al., 2013).

Uranium $\left({ }^{238} \mathrm{U}\right)$, Thorium $\left({ }^{232} \mathrm{Th}\right)$ and their decay products $\left({ }^{226} \mathrm{Ra},{ }^{212} \mathrm{~Pb}\right.$, etc.) and Potassium isotope $\left({ }^{40} \mathrm{~K}\right)$ are the natural radionuclides observed as inherent soil contents with known contribution to the radiation exposure and emission of gamma ray and subsequent ingestion through inhalation and the food chain (Mujahid \& Hussain, 2011).

The potential radiological hazards parameters investigated in this study include the radium equivalent activity $\left(R a_{e q}\right)$, the annual effective dose rate $\left(H_{\mathrm{R}}\right)$, external hazard $\left(H_{\mathrm{ex}}\right)$ and internal hazard $\left(H_{\mathrm{in}}\right)$ indices, Representative Gamma Index $\left(I_{\gamma r}\right)$ and Excess Lifetime Cancer Risk (ELCR). Others (not considered in this study) are the activity utilization index $(I)$, and the alpha index $\left(I_{\alpha}\right)$. The knowledge of radionuclides distribution and radiation levels in the environment is important for assessing the effects of radiation exposure due to both terrestrial and extra-terrestrial sources (Rajesh et al., 2013). If the values of the hazard indices are below the recommended levels; therefore, it is concluded that the environment is relatively safe. 


\section{Study Area}

Okobo community, is a small town in Enjema district of Ankpa Local Government Area $\left(7^{\circ} 22^{\prime} 14^{\prime \prime} \mathrm{N}, 7^{\circ} 37^{\prime} 31^{\prime \prime} \mathrm{E}\right)$ in Kogi state with reserves of up to 380 million tonnes of coal.

Studies on radiological hazards and detriments are widely documented $(\mathrm{Ba}-$ chama et al., 2017; Alausa et al., 2019; llori \& Alausa, 2019). In this study, we focus on the levels of radiation exposure due to the natural radionuclides $\left({ }^{238} \mathrm{U}\right.$, ${ }^{232} \mathrm{Th}$ and ${ }^{40} \mathrm{~K}$ ) in Okobo coal and their vicinity soils, water and cassava plants. The study, for the first time unveiled the radiological detriments associated with the impact of coal mine activities within the study area.

\section{Materials and Methods}

Analytical grade reagents were used in this study. Instrument employed for analysis include high resolution gamma spectrometer at the Center for Energy Research and Training (CERT), Ahmadu Bello University Zaria, consisting of high purity germanium (HPGe) detector, by Ortec Inc., connected to an Ortec series multichannel analyzer (MCA) through a preamplifier base and coupled to a personal computer. Water samples were analyzed using the liquid scintillation counter (Tri-CarbLSA1000).

\subsection{Sampling}

Water sampling at Okobo coal field was carried out from the months of November to December, 2018 and January, 2019. Method, described in Table 1 for the first stage of this study (Itodo et al., 2020) was followed. Water samples were collected at a depth of $2-10 \mathrm{~cm}$ at the water surface using a 1litre plastic container with a screw cap, with respect to the coal mining operation site. Water samples were collected between 7 am and $10 \mathrm{am}$ ) in triplicates from 3 locations (50 cm upstream, midstream and downstream) with pre-cleaned glass bottles. The samples in $1-\mathrm{L}$ amber bottles were adjusted to $\mathrm{pH}<2$ using $6 \mathrm{M}$ of hydrochloric acid (Adeniji et al., 2019).

Table 1. Sampling codes and description.

\begin{tabular}{ccc}
\hline S/N & Sample ID & Description \\
\hline 1 & OC & Okobo coal \\
2 & SS & Soil Sample \\
3 & CSS & Control soil sample \\
4 & WS & Water sample \\
5 & CWS & Control water sample \\
6 & CS & Cassava sample \\
7 & CCS & Control cassava sample
\end{tabular}


Soil sampling method reported by Usikalu et al. (2017) was adopted. The vicinity of Okobo coal mine was divided into four quadrants. Soil samples were obtained from each of these quadrants which was $200 \mathrm{~m}$ apart from one another and the harmonized into a representative sample. The samples were collected by digging the ground to at least $3 \mathrm{~cm}$. Five soil samples were taken from different points at each location, using composite sampling method. The samples were then kept in airtight bags and labelled accordingly. The samples were dried at $110^{\circ} \mathrm{C}$ in an oven to ensure complete removal of moisture until constant weight was attained. Dried samples were grinded and passed through a $2 \mathrm{~mm}$ sieve. $100 \mathrm{~g}$ of each sample were placed in a radon-tight plastic vessel. The vessels were weighted and sealed for 30 days to allow equilibrium in the ${ }^{238} \mathrm{U}$ and ${ }^{232} \mathrm{Th}$ with their respective progeny.

Coal collection was based on methods documented by Odunayo et al. (2016) and Querol et al. (1996) were carefully followed. A sample grid was established in which five samples of mass $20 \mathrm{~g}$ of coal was obtained from a split which was taken each $50 \mathrm{~m}$ away from the grid and then harmonized as one sample by means of a hand trowel and a hammer at the coal site. A gross sample of $60 \mathrm{~g}$ was obtained after homogenisation of the five samples. The gross coal samples were air-dried, milled and split carefully to obtain a representative $10 \mathrm{~g}$ sub-sample of particle size $<250 \mu \mathrm{m}$. Coal sample preparation involved crushing, screening and storage. In crushing of coal, samples were reduced to smaller sizes by mechanical means, followed by pulverising in a rotary mill. The powdered samples were passed through a 210 micron sieve to prepare a representative $50 \mathrm{~g}$ sub-sample for analysis. The sample was tagged as Okobo coal (OC).

Cassava samples were randomly collected as donations based on farm basket approach. Control samples for the duo (soil and cassava) were collected from Ogaji district (6 - $7 \mathrm{~km}$ away from Okobo), following similar protocol. Control water sample is a commercial and registered potable water.

\section{2. $\gamma$-Ray Spectrometric NaI(Tl) Analysis}

The soil, coal and cassava samples were dried and crushed to fine powder with the use of pulverizer. Packaging of the samples into radon impermeable cylindrical plastic containers was selected based on the space allocation of the detector vessel. To prevent radon-222 escape, the packaging in each case was triple sealed, which included smearing of the inner rim of each container lid with Vaseline jelly, filling the lid assembly gap with candle wax to block the gap between lid and container and tight-sealing lid container with masking adhesive tape. Radon and its short lived progenies were allowed to reach secular radioactive equilibrium by storing the samples for 30 days prior to gamma spectroscopy measurement.

The $\gamma$-ray spectrometer $\mathrm{NaI}(\mathrm{Tl})$ is equipped with $\mathrm{NaI}(\mathrm{Tl})$ detector that measures the natural radio-nuclides activity (count rate in the environmental samples). It was calibrated using known source such as ${ }^{60} \mathrm{Co}$ and ${ }^{137} \mathrm{Cs}$ point sources. In order to calculate the radionuclide activity concentration (activity per unit mass) 
for each gamma ray photo-peak, we rely on the secular equilibrium between parents and daughters in the samples, the Equation (1) was used (Alashrah \& Taher, 2017).

The analysis was carried out using a $76 \times 76 \mathrm{~mm} \mathrm{NaI}(\mathrm{Tl})$ detector crystal optically coupled to a photomultiplier tube (PMT). The assembly has a preamplifier incorporated into it and a 1 kilovolt external source. The detector is enclosed in a $6 \mathrm{~cm}$ lead shield with cadmium and copper sheets. This arrangement is aimed at minimizing the effects of background and scattered radiation. The samples were measured for a period of 29,000 seconds, for each sample. The peak area of each energy in the spectrum was used to compute for the activity concentrations in each sample by the use of the following equation:

$$
C\left(\mathrm{~Bq} \cdot \mathrm{kg}^{-1}\right)=\frac{C_{n}}{C_{f k}}
$$

where:

$C=$ activity concentration of the radionuclides in the sample given in $\mathrm{Bq} \cdot \mathrm{Kg}^{-1}$;

$C_{n}=$ count rate (counts per second).

$$
\text { Count per second }(\mathrm{cps})=\frac{\text { Net Count }}{\text { Live Time }}
$$

$C_{f k}=$ Calibration factor of the detecting system.

The measuring time for gamma-ray spectra was $43,200 \mathrm{~s}$. To obtain the same gamma dose rate, the activity concentration from the three radionuclides assuming to be $370 \mathrm{~Bq} \cdot \mathrm{kg}^{-1}$ from ${ }^{226} \mathrm{R}, 259 \mathrm{~Bq} \cdot \mathrm{kg}^{-1}$ from ${ }^{232} \mathrm{Th}$ and $4810 \mathrm{~Bq} \cdot \mathrm{kg}^{-1}$ from ${ }^{40} \mathrm{~K}$. This is the definition of radium equivalent and is given as Equation (3):

$$
R a_{e q}=A_{\mathrm{Ra}}+1.43 \times A_{\mathrm{Th}}+0.077 \times A_{\mathrm{K}}
$$

where $A_{\mathrm{Ra}}, A_{\mathrm{Th}}$ and $A_{\mathrm{K}}$ are the activity concentrations of ${ }^{226} \mathrm{Ra},{ }^{232} \mathrm{Th}$ and ${ }^{40} \mathrm{~K}$ in $\mathrm{Bq} \cdot \mathrm{kg}^{-1}$, respectively.

\subsection{Liquid Scintillation Counting}

Water sample $(10 \mathrm{~mL})$ was added into a scintillation vial containing $10 \mathrm{~mL}$ of installgel scintillation cocktail and analyzed using the liquid scintillation counter (Tri-CarbLSA1000). Initial Counting was carried out immediately the prepared samples were brought to the laboratory. Two litters of water sample treated with $10 \mathrm{~mL}$ of concentrated Nitric acid were used for each sample. Evaporation was achieved using beaker $(500 \mathrm{~mL})$ set on hot plate at a steady temperature below boiling point to avoid boiling of the water sample. This prevents loss of much residue. The volume evaporated was taken and recorded. After surface drying, residual volume was transferred into Petri-dish for further drying to give final dried residue. Residue was weighed and transferred into planchet, followed by addition of drops of acetone and vinyl-acetate. The vinyl-acetate helps in removing the moisture content and serves as a binder while the acetone was used as sterilizer. Then the sample is ready for counting. 


\subsection{Calibration and Calibration Efficiency}

Table 2 represents the spectral energy calibration data used in the analysis. The beta standards are Strontium-90 beta sources of diameter $38 \mathrm{~mm}$ and active film of $12 \mathrm{mg} / \mathrm{m}^{3}$ thick. The alpha standards are Plutonium-239 alpha sources of diameter $38 \mathrm{~mm}$ in an oxidable disc of $3 \mathrm{~mm}$ thick. $10 \mathrm{~mL}$ of concentrated nitric acid were added to the water sample immediately after collection so as to reduce the $\mathrm{pH}$, minimize precipitation and prevent the absorption on the wall of the container. The calculation formulae for the count rate and activity are:

$$
\text { Count rate }:(\alpha, \beta)=\frac{\text { Raw count }}{\text { Count Time }}
$$

Calibration of the system for energy and efficiency were done with two calibration point sources, Cs-137 and Co-60. These were done with the amplifier gain that gives $72 \%$ energy resolution for the $66.16 \mathrm{Kev}$ of Cs-137 and counted for 30 minutes.

Table 3 stands for quality control parameters for quantitative spectral analysis. The standards used to check for the calibration are the IAEA gamma Spectrometric reference materials RGK-1 for K-40, RGU-1 for Ra-226 (Bi-214 peak) and RTG-1 for Th-232 (Ti-208). The background count rate was done for 29,000 seconds just as those of the samples.

Gamma ray spectroscopic systems were used to analyze the samples collected. The radiation source was placed close to the detector in order to increase the intensity reaching the detector hence; the counting system may exhibit high detection efficiency (Bello et al., 2014). The net count was obtained using the expression:

$$
N_{S}=N_{g}-N_{b}
$$

where $N_{s}=$ Sample counts (Net counts), $N_{b}=$ Background counts, $N_{g}=$ Gross counts .

Table 2. Spectral energy windows used in the analysis.

\begin{tabular}{ccc}
\hline Radio-isotope & Gamma Energy $(\mathrm{Kev})$ & Energy Window $(\mathrm{Kev})$ \\
\hline R-226 & 1764.0 & $1620-1820$ \\
Th-232 & 2614.5 & $2480-2820$ \\
K-40 & 1460.0 & $1380-1550$ \\
\hline
\end{tabular}

Table 3. Quality control parameters for quantitative spectral analysis.

\begin{tabular}{cccccc}
\hline \multicolumn{2}{c}{ Calibration Factor } & & Detection Limit \\
\hline Radio-Isotopes & $10^{-3}(\mathrm{cps} / \mathrm{ppm})$ & $10^{-4}(\mathrm{cps} / \mathrm{ppm})$ & $\begin{array}{c}\text { Conversion Factor } \\
\left(\mathrm{Bq} \cdot \mathrm{Kg}^{-1}\right)\end{array}$ & $\mathrm{ppm}$ & $\mathrm{Bq} / \mathrm{kg}$ \\
\hline${ }^{40} \mathrm{~K}$ & 0.026 & 6.431 & 0.032 & 454.54 & 14.54 \\
${ }^{226} \mathrm{Ra}$ & 10.500 & 8.632 & 12.20 & 0.32 & 3.84 \\
${ }^{232} \mathrm{Th}$ & 3.612 & 8.768 & 4.12 & 2.27 & 9.08 \\
\hline
\end{tabular}


The activity concentration $\left(\mathrm{Bq} \cdot \mathrm{kg}^{-1}\right)$ of each radionuclide was obtained using:

$$
\text { Sample activity }(C)=\frac{N_{s}}{\varepsilon y t m}
$$

where $\varepsilon=$ efficiency detector, $y=$ gamma yield, $m=$ mass of the sample, $t=$ counting time.

\section{Results and Discussion}

\subsection{Visual Inspection of Samples}

The sampling sites for cassava, soil and water samples were presented in Figure 1. The physical outlay of cassava farm land from Okobo coal-mining areas physically shows varieties of stunted growth of cassava samples. Outburst of suspected polluted water from the coal mining regions in both downstream and upstream water samples from Okobo vicinity were well observed as coloured due to coal deposits and leachates. This is the only source of water for industrial, agricultural and domestic uses in Okobo.

\subsection{Radiological Study}

Results of radiological study for soil, coal and cassava samples from Okobo coal mine is presented in Tables 4-6. Table 4 shows the $\mathrm{K}-40$ radiological data of water samples measured with liquid scintillation counter. K-40 counts do not follow a regular trend. Values recorded for upstream water samples (49.95 - 111.32 $\mathrm{cpm}$ ) exceed those reported for mid and down streams. This is an indication that the upstream water is more contaminated with $\mathrm{K}-40$ radionuclide.

\subsection{Activity Concentrations of K-40 in Water Samples}

The radiological analysis of water samples by Gamma ray liquid scintillation at 60-minute count rate shown in Table 4 was converted to activity concentrations (Table 5) using the conversation factor of $\mathrm{cps} / \mathrm{Bq} \cdot \mathrm{Kg}^{-1}=0.000643$ for $\mathrm{K}-40$. Table 5 revealed that the control water sample (CWS1 and CWS2) has high K-40 content, with mean activity concentration range of $96.15-1129.69 \mathrm{~Bq} \cdot \mathrm{kg}^{-1}$. Next to this value is the upstream K-40 mean activity concentration of $934.86 \mathrm{~Bq} \cdot \mathrm{kg}^{-1}$. The trend of k-40 activity concentration follows the order of US > MS > DS as shown in Figure 2. K-40 isotope values estimated for the analytical water samples are below those recorded for the IAEA reference water samples $\left(785-1150.51 \mathrm{~Bq} \cdot \mathrm{kg}^{-1}\right)$.

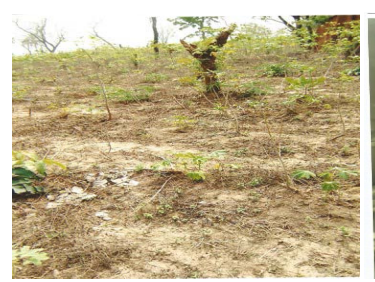

(a)

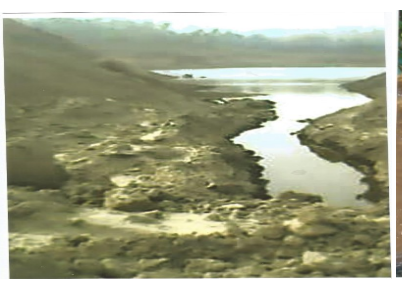

(b)

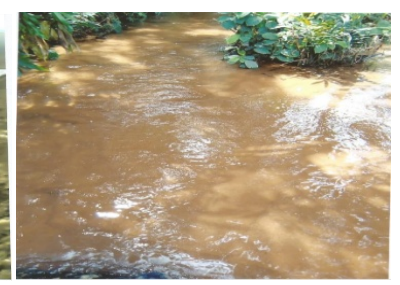

(c)

Figure 1. Study area showing (a) Cassava plants (with Stunted Growth), (b) Outburst of water from coal mine site, (c) Downstream water samples in Okobo. 
Table 4. Radiological data (counts per minutes) of K-40 in water samples from Okobo coal mine, using gamma ray liquid scintillation counter.

\begin{tabular}{lcccc}
\hline \multirow{2}{*}{ S/n } & \multirow{2}{*}{ Sample I.D } & \multicolumn{3}{c}{ Radiological Data (cpm) } \\
\cline { 3 - 5 } & & Channel A & Channel B & Channel C \\
\hline 1 & CWS 1 & 66.08 & 61.17 & 134.25 \\
2 & CWS 2 & 54.22 & 48.95 & 108.90 \\
3 & US & 55.13 & 49.95 & 111.32 \\
4 & MS & 47.85 & 43.42 & 96.33 \\
5 & DS & 47.98 & 39.07 & 91.08 \\
6 & BW & 64.22 & 45.57 & 117.22 \\
7 & IAEA 423(R1) & 39.65 & 49.27 & 92.93 \\
8 & IAEA427(R2) & 70.83 & 61.57 & 133.92 \\
9 & IAEA 431(R3) & 53.08 & 50.52 & 106.43 \\
\hline
\end{tabular}

$\mathrm{CPM} / \mathrm{K}=\mathrm{K}-40$ Count Per Minute Channel A, IAEA423 = International Atomic, Energy Agency 423 Calibration Factor of Liquid Scintillation's counter is 13.37, BW= Background water.

Table 5. Activity concentrations of K-40 in water samples.

\begin{tabular}{cccccc}
\hline \multirow{2}{*}{ S/n } & Sample id & \multicolumn{3}{c}{ Activity concentration $\left(\mathrm{Bq}^{\mathrm{k}} \mathrm{kg}^{-1}\right)$} \\
\cline { 3 - 5 } & & Channel A & Channel B & Channel C & Mean values \\
\hline 1 & CWS 1 & 856.40 & 792.77 & 1739.89 & 1129.69 \\
2 & CWS 2 & 702.70 & 634.40 & 1411.35 & 916.15 \\
3 & US & 714.49 & 647.36 & 1442.72 & 934.86 \\
4 & MS & 620.14 & 562.73 & 1248.44 & 810.46 \\
5 & DS & 621.82 & 506.35 & 1180.40 & 769.52 \\
6 & BW & 832.30 & 590.59 & 1519.18 & 980.69 \\
7 & IAEA 423 (R1) & 513.87 & 638.54 & 1204.38 & 785.60 \\
8 & IAEA427 (R2) & 917.96 & 797.95 & 1735.61 & 1150.51 \\
9 & IAEA 431 (R3) & 687.92 & 654.74 & 1379.34 & 907.33 \\
\hline
\end{tabular}

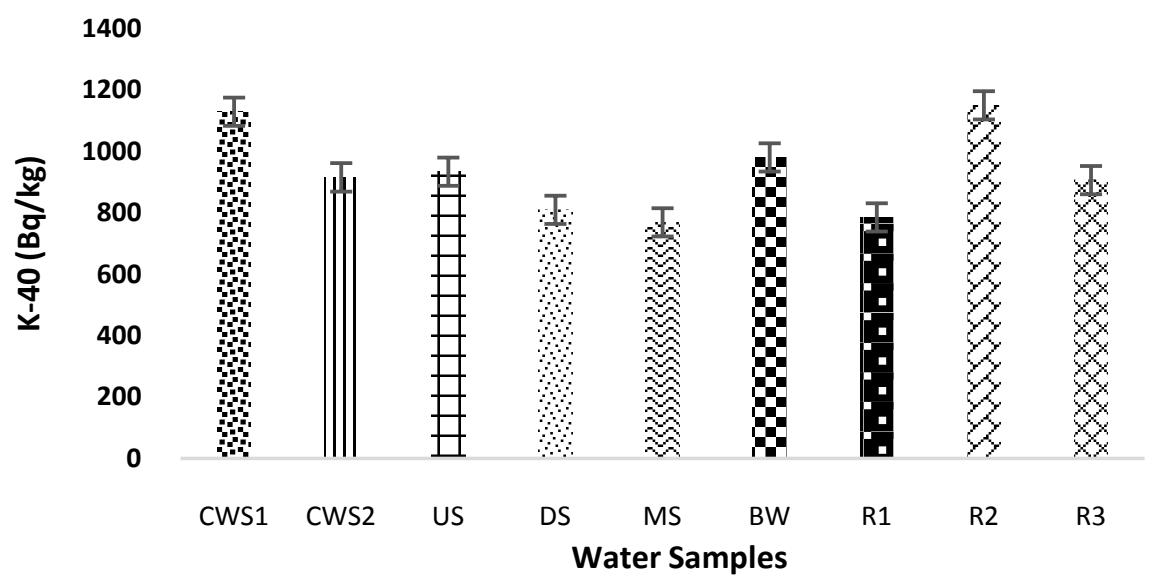

Figure 2. Mean activity concentrations $(\mathrm{Bq} / \mathrm{Kg})$ of $\mathrm{K}-40$ in water samples from Okobo coal mine. 
Table 6 represents the radiological data (counts) for Okobo coal, soil and cassava samples. Activity concentration levels of naturally available K-40, Ra-226 and Th-232 were presented in Table 7. This study shows that the control soil from

Table 6. Radiological data (counts per second) for soil, coal and cassava samples from Okobo coal Mine site.

\begin{tabular}{cccccccc}
\hline \multirow{2}{*}{ S/N } & \multirow{2}{*}{ Sample ID } & \multicolumn{7}{c}{ Radiological Data (cps) } \\
\cline { 3 - 7 } & & K-40 & SD & Ra-226 & SD & Th-232 & SD \\
\hline 1 & CSS & 0.0452 & 0.006 & 0.0983 & 0.0022 & 0.0010 & 0.0008 \\
2 & SS 1 & 0.0948 & 0.0010 & 0.0232 & 0.0034 & 0.0433 & 0.0022 \\
3 & SS 2 & 0.1208 & 0.0017 & 0.0146 & 0.0020 & 0.0466 & 0.0019 \\
4 & SS 3 & 0.0846 & 0.0022 & 0.0184 & 0.0021 & 0.0682 & 0.0014 \\
5 & SS 4 & 0.0774 & 0.0012 & 0.0669 & 0.0010 & 0.0545 & 0.0011 \\
6 & SS 5 & 0.0693 & 0.0030 & 0.0376 & 0.0025 & 0.0660 & 0.0013 \\
7 & CCS & 0.1493 & 0.0032 & 0.0433 & 0.0010 & 0.0534 & 0.0011 \\
8 & CS 1 & 0.0733 & 0.0026 & 0.0078 & 0.0012 & 0.0560 & 0.0010 \\
9 & CS 2 & 0.1860 & 0.0026 & 0.0415 & 0.0035 & 0.0449 & 0.0015 \\
10 & CS 3 & 0.1662 & 0.0033 & 0.0072 & 0.0016 & 0.0583 & 0.0012 \\
11 & CS 4 & 0.1609 & 0.0060 & 0.0951 & 0.0023 & 0.1113 & 0.0023 \\
12 & CS 5 & 0.1187 & 0.0039 & 0.0123 & 0.0013 & 0.0316 & 0.0013 \\
13 & OC & 0.1014 & 0.0012 & 0.0134 & 0.0022 & 0.0424 & 0.0017 \\
\hline
\end{tabular}

$\mathrm{CPS}=$ Count per second; $\mathrm{Bq} / \mathrm{Kg}=$ Becquerel per Kilogram; Calibration Factors: $\times 10^{-4}$; Conversion Factor: $\mathrm{cps} / \mathrm{Bq} \cdot \mathrm{Kg}^{-1} ; \mathrm{K}-40=0.000643, \mathrm{Ra}-226=0.000643, \mathrm{Th}-232=0.000877$.

Table 7. Activity concentrations of samples from Okobo coal mine vicinity.

\begin{tabular}{cccccccc}
\hline \multirow{2}{*}{ S/N } & Sample ID & \multicolumn{7}{c}{ Activity concentrations $\left(\mathrm{Bq} \cdot \mathrm{kg}^{-1}\right)$} \\
\cline { 3 - 7 } & & K-40 & SD & Ra-226 & SD & Th-232 & SD \\
\hline 1 & CSS & 29.07 & 0.35 & 47.10 & 1.00 & 0.47 & 0.35 \\
2 & SS 1 & 147.48 & 1.61 & 26.93 & 4.00 & 49.35 & 2.52 \\
3 & SS 2 & 187.91 & 2.63 & 16.86 & 2.36 & 53.08 & 2.20 \\
4 & SS 3 & 131.60 & 3.38 & 21.38 & 2.48 & 77.77 & 1.57 \\
5 & SS 4 & 120.45 & 1.82 & 77.56 & 1.20 & 62.12 & 1.22 \\
6 & SS 5 & 107.74 & 4.72 & 43.55 & 2.88 & 75.26 & 1.53 \\
7 & CCS & 232.26 & 4.99 & 50.23 & 1.16 & 60.91 & 1.26 \\
8 & CS 1 & 113.96 & 3.97 & 9.03 & 1.44 & 63.85 & 1.10 \\
9 & CS 2 & 289.32 & 4.02 & 48.11 & 4.04 & 55.79 & 1.73 \\
10 & CS 3 & 258.54 & 5.09 & 8.39 & 1.80 & 66.49 & 1.38 \\
11 & CS 4 & 103.55 & 0.39 & 45.58 & 1.12 & 52.53 & 1.10 \\
12 & CS 5 & 184.53 & 6.01 & 14.26 & 1.52 & 36.02 & 1.53 \\
13 & OC & 157.67 & 1.88 & 15.58 & 2.60 & 48.40 & 1.97 \\
& Min & 29.07 & 0.35 & 8.39 & 1.00 & 0.47 & 0.35 \\
& Max & 289.32 & 6.01 & 77.56 & 4.04 & 77.77 & 2.52 \\
& Mean & 158.78 & 3.14 & 32.66 & 2.12 & 54.00 & 1.50 \\
\hline
\end{tabular}

CPS $=$ Count per second, $\mathrm{Bq} / \mathrm{Kg}=$ Becquerel per Kilogram, Calibration Factors: $\times 10^{-4}$, Conversion Factor: $\mathrm{cps} / \mathrm{Bq} \cdot \mathrm{Kg}^{-1}, \mathrm{~K}-40=0.000643, \mathrm{Ra}-226=0.000643, \mathrm{Th}-232=0.000877$. 
the non-coal region records the least activity concentrations of K-40 (29.07), Ra-226 (47.18) and Th-232 (0.47) Bq. $\mathrm{kg}^{-1}$. A corresponding high level was observed for control cassava samples. This could be attributed to the soft cassava tissue and their affinity for the sorption of radionuclides at short period.

\subsection{Activity Concentrations of Radionuclides in Coal Sample}

The range of activities obtained for the studies showed the mean concentrations as: ${ }^{226} \mathrm{Ra}\left(8.39 \pm 1.00\right.$ to $\left.77.56 \pm 4.04 \mathrm{~Bq} \cdot \mathrm{kg}^{-1}\right),{ }^{232} \mathrm{Th}(0.47 \pm 0.35$ to $77.77 \pm 2$ $\left.\mathrm{Bq} \cdot \mathrm{kg}^{-1}\right)$ and for ${ }^{40} \mathrm{~K}\left(29.07 \pm 0.35\right.$ to $\left.289.32 \pm 6.01 \mathrm{~Bq} \cdot \mathrm{kg}^{-1}\right)$, with respective mean values of $32.66 \pm 2.12,54.00 \pm 1.50$ and $158.78 \pm 3.14 \mathrm{~Bq} \cdot \mathrm{kg}^{-1}$ respectively. The coal sample itself has values of $15.58 \pm 2.60 \mathrm{~Bq} \cdot \mathrm{kg}^{-1}$ for ${ }^{226} \mathrm{Ra}, 48.40 \pm 1.97 \mathrm{~Bq} \cdot \mathrm{kg}^{-1}$ for ${ }^{232} \mathrm{Th}$ and $158.78 \pm 3.14 \mathrm{~Bq} \cdot \mathrm{kg}^{-1}$ for ${ }^{40} \mathrm{~K}$. The activity concentrations of ${ }^{226} \mathrm{Ra}$ is below the $20 \mathrm{~Bq} \cdot \mathrm{kg}^{-1}$, while those of ${ }^{232} \mathrm{Th}$, and ${ }^{40} \mathrm{~K}$ are above the $20 \mathrm{~Bq} \cdot \mathrm{kg}^{-1}$ and $50 \mathrm{~Bq} \cdot \mathrm{kg}^{-1}$ above the world average values for coal (UNSCEAR, 1982).

\subsection{Radiological Data for Soil and Cassava Samples}

Figure 3 indicted activity concentration trend of K-40 > Th-232 > Ra-226. The affinity of the control (non-coal region) cassava sample for Th-232 is higher compared to the corresponding soil sample, CSS. The high radionuclides activity concentrations of analytical samples compared to the coal itself could be attributed to bioaccumulation and sample size considered in the study.

\subsection{Hazard Indices}

Table 8 represent the radiological detriments attributed to radionuclides estimated in Okobo coal and their near environmental samples. Table 8 contains calculations of Radium equivalent activity $\left(R a_{e q}\right)$, External hazard index $\left(H_{e x}\right)$, internal hazard index $\left(H_{i n}\right)$, Representative gamma index $\left(I_{\gamma r}\right)$ and Excess lifetime cancer risk (ELCR).

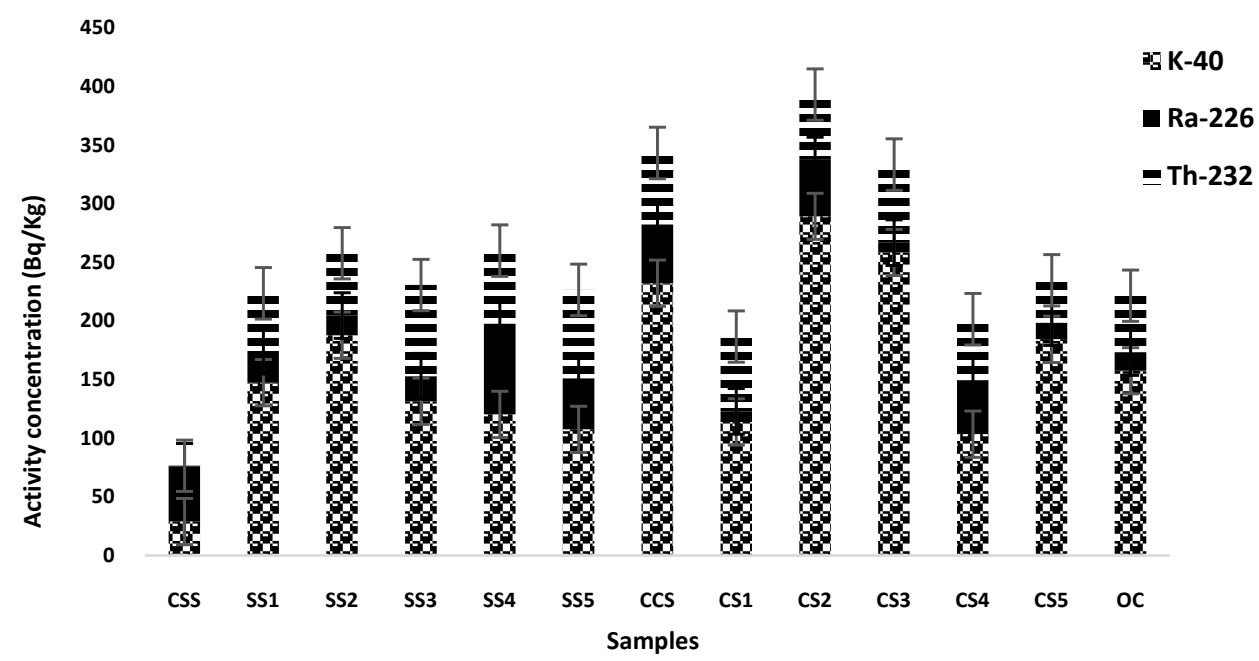

Figure 3. Mean activity concentrations (Bq/Kg) of radionuclides $\left({ }^{40} \mathrm{~K},{ }^{226} \mathrm{Ra}\right.$ and $\left.{ }^{228} \mathrm{Th}\right)$ of coal, soil and plant samples from Okobo coal mine site. 


\subsubsection{Radium Equivalent Activity $\left(R a_{e q}\right)$}

${ }^{226} \mathrm{Ra}$, ${ }^{232} \mathrm{Th}$, and ${ }^{40} \mathrm{~K}$ are not uniformly distributed in most environmental samples. This is shown in their respective radio hazard indices. A single parameter known as Radium equivalent activity $\left(R a_{e q}\right)$ in Table 8 is defined with respect to radiation exposure which compares the activity of materials containing different elements of primordial radionuclides. Its definition also considers external and internal effective dose from radon and its decay progeny (Huang et al., 2015). $R a_{e q}$ is measured in $\mathrm{Bq} \cdot \mathrm{kg}^{-1}$ and defined based on the assumption that specific activity of $370 \mathrm{~Bq} \cdot \mathrm{kg}^{-1}$ for ${ }^{226} \mathrm{Ra}$ uniformly distributed in any environmental sample can result in annual effective dose of $1 \mathrm{mSv}$ at $1 \mathrm{~m}$ above ground level (Huang et al., 2015; Taskin et al., 2009). It is quantitatively expressed as (Beretka \& Mathew, 1985; UNSCEAR, 2000).

$$
R a_{e q}\left(\mathrm{~Bq} \cdot \mathrm{kg}^{-1}\right)=A_{\mathrm{Ra}}+1.43 A_{\mathrm{Th}}+0.077 A_{\mathrm{K}}
$$

where $A_{\mathrm{Ra}}, A_{\mathrm{Th}}$ and $A_{\mathrm{K}}$ are the respective specific activities of ${ }^{226} \mathrm{Ra},{ }^{232} \mathrm{Th}$, and ${ }^{40} \mathrm{~K}$. The constants; $1,1.43$, and 0.077 , represents the activity conversion rates for ${ }^{226} \mathrm{Ra},{ }^{232} \mathrm{Th}$, and ${ }^{40} \mathrm{~K}$ in sequence, which result in gamma dose rate at maximum permissible $R a_{e q}$ of $370 \mathrm{~Bq} \cdot \mathrm{kg}^{-1}$. The result of $R a_{e q}\left(\mathrm{~Bq} \cdot \mathrm{kg}^{-1}\right)$ in this study (Table 8) revealed the contributions of coal mining to vicinity environmental samples. The values reported for CSS (50.01 Bq. $\mathrm{kg}^{-1}$ ) is far less than those of the analytical soil samples (107.24 - 175.67 Bq. $\left.\mathrm{kg}^{-1}\right)$ as well as their corresponding cassava samples (79.98 - $150.17 \mathrm{~Bq} \cdot \mathrm{kg}^{-1}$ ). Figure 4 unveiled the difference between the Radium activity and detriment in cassava as higher compared to soils.

Table 8. Radiological detriments (Hazard Indices) of coal, soil and cassava samples from Okobo mine site.

\begin{tabular}{ccccccc}
\hline S/N & Sample ID & \multicolumn{5}{c}{ Sample ID } \\
\cline { 3 - 6 } & & $R a_{e q}\left(\mathrm{~Bq} \cdot \mathrm{kg}^{-1}\right)$ & $H_{\text {ex }}$ & $H_{\text {in }}$ & $I_{\gamma r}$ & ELCR $\left(\times 10^{-3}\right)$ \\
\hline 1 & CSS & 50.01 & 0.14 & 0.26 & 0.34 & 0.89 \\
2 & SS 1 & 108.85 & 0.29 & 0.37 & 0.77 & 1.77 \\
3 & SS 2 & 107.24 & 0.29 & 0.34 & 0.77 & 1.73 \\
4 & SS 3 & 142.73 & 0.39 & 0.44 & 1.01 & 2.25 \\
5 & SS 4 & 175.67 & 0.47 & 0.68 & 1.22 & 2.89 \\
6 & SS 5 & 159.47 & 0.43 & 0.55 & 1.11 & 2.55 \\
7 & CCS & 155.20 & 0.42 & 0.55 & 1.10 & 2.56 \\
8 & CS 1 & 109.12 & 0.29 & 0.32 & 0.77 & 1.71 \\
9 & CS 2 & 150.17 & 0.41 & 0.54 & 1.07 & 2.50 \\
10 & CS 3 & 123.38 & 0.33 & 0.36 & 0.89 & 1.98 \\
11 & CS 4 & 128.67 & 0.35 & 0.47 & 0.90 & 2.09 \\
12 & CS 5 & 79.98 & 0.22 & 0.25 & 0.58 & 1.31 \\
13 & OC & 96.94 & 0.26 & 0.30 & 0.69 & 1.56 \\
& Min & 50.01 & 0.14 & 0.25 & 0.34 & 0.89 \\
& Max & 175.67 & 0.47 & 0.68 & 1.22 & 2.89 \\
& Mean & 122.11 & 0.33 & 0.42 & 0.86 & 1.98 \\
\hline
\end{tabular}




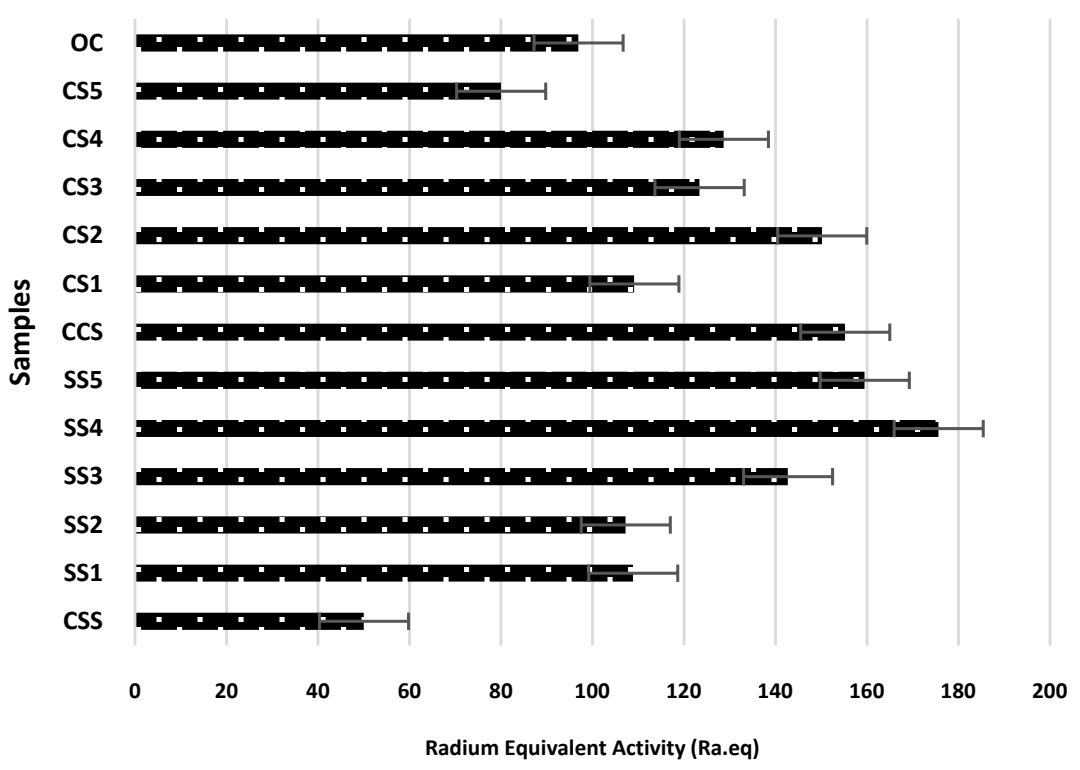

Figure 4. Radium equivalent activity $\left(R a_{e q}\right)$ of coal, soil and plant samples from Okobo coal mine site.

\subsubsection{External Hazard Index $\left(H_{e x}\right)$}

Radiation hazard incurred due to external exposure to gamma rays is quantified in terms of the external hazard index $\left(H_{e x}\right)$. The maximum permissible value for $H_{e x}$ is unity, which corresponds to $R a_{e q}$ upper limit of $370 \mathrm{~Bq} \cdot \mathrm{kg}^{-1}$ (Huang et al., 2015; Oni, 2019). $H_{e x}$ is calculated from the equation:

$$
H_{e x}=\frac{A_{\mathrm{Ra}}}{370}+\frac{A_{\mathrm{Th}}}{259}+\frac{A_{\mathrm{K}}}{4810}
$$

where $A_{\mathrm{Ra}}, A_{\mathrm{Th}}$, and $A_{\mathrm{K}}$ are the specific activities of ${ }^{226} \mathrm{Ra},{ }^{232} \mathrm{Th}$, and ${ }^{40} \mathrm{~K}$, respectively. It is assumed that $370 \mathrm{~Bq} \cdot \mathrm{kg}^{-1}$ of ${ }^{226} \mathrm{Ra}, 259 \mathrm{~Bq} \cdot \mathrm{kg}^{-1}$ of ${ }^{232} \mathrm{Th}$, and 4810 $\mathrm{Bq} \cdot \mathrm{kg}^{-1}{ }^{40} \mathrm{~K}$, produce the same gamma dose rate (Lu et al., 2006; Lu et al., 2012). Values of Hex $(0.14-0.47)$ computed for coal, soil and cassava samples in this study were below unity, hence within the permissible limit with sample tagged as non-hazardous with reference to radionuclides.

\subsubsection{Internal Hazard Index $\left(H_{i n}\right)$}

The internal radiation exposure is quantified by the internal hazard index (Hin) given by UNSCEAR (Gawlik \& Bidoglio, 2006).

$$
H_{\text {in }}=\frac{A_{\mathrm{Ra}}}{185}+\frac{A_{\text {Th }}}{259}+\frac{A_{\mathrm{K}}}{4810}
$$

where, $A_{\mathrm{Ra}}, A_{\mathrm{Th}}$, and $A_{\mathrm{K}}$ are the specific activities of ${ }^{226} \mathrm{Ra}$, ${ }^{232} \mathrm{Th}$, and ${ }^{40} \mathrm{~K}$, respectively. UNSCEAR (2000) provided that the value of the above indices must be less than unity for the radiation hazard to be regarded as insignificant as exemplified in this studies. $H_{\text {in }}$ values ranged from $0.25-0.68$ across soil, coal and cassava samples within the Okobo coal field and environment.

\subsubsection{Representative Gamma Index $\left(I_{\gamma r}\right)$}

The representative gamma index $\left(I_{\gamma r}\right)$ is a screening parameter for materials of 
possible radiation health challenge (Jibiri \& Okeyode, 2012). It is calculated using the equation (Ravisankar et al., 2014).

$$
I_{\gamma r}=\frac{A_{\mathrm{Ra}}}{150}+\frac{A_{\mathrm{Th}}}{100}+\frac{A_{\mathrm{K}}}{1500}
$$

where $A_{\mathrm{Ra}}, A_{\mathrm{Th}}$, and $A_{\mathrm{K}}$ are the specific activity concentrations of ${ }^{226} \mathrm{Ra}$, ${ }^{232} \mathrm{Th}$, and ${ }^{40} \mathrm{~K}$, respectively, in Bq. $\mathrm{kg}^{-1}$. The numerical denominators of 150,100 , and 1500 , are specific exposure rates for ${ }^{226} \mathrm{Ra},{ }^{232} \mathrm{Th}$, and ${ }^{40} \mathrm{~K}$, respectively that yield a sum of $I_{y r}<1$, which corresponds to an annual effective dose of $<1 \mathrm{mSv}$, to satisfy the dose criteria (Manigandan \& Chandar-Shekar, 2014; Taskin et al., 2009). Samples estimated in this study gave Representative Gamma Index values, ranging betwee $0.34-1.22$. This implied that there could be possible radiation health challenges resulting from some samples whose annual gamma effective dose tends to unity or $<1 \mathrm{mSv}$. On the average, $I_{y r}$ values for this study is 0.86 .

\subsubsection{Excess Lifetime Cancer Risk (ELCR)}

Excess life-time cancer risk (ELCR) was estimated from annual effective dose equivalent using the equation (Ravisankar et al., 2014; Taskin et al., 2009)

$$
\mathrm{ELCR}=\mathrm{AEDE} \times \mathrm{DL} \times \mathrm{RF}
$$

where AEDE, DL, and RF are the annual effective dose equivalent, duration of life (70 years), and risk factor $\left(0.05 \mathrm{~Sv}^{-1}\right)$, respectively (Ravisankar et al., 2014). This parameter defined the risk factor as fatal cancer risk per Sievert, which according to Taskin et al. (2009) is assigned a value of 0.05 by ICRP 60 for the public for stochastic effects. Figure 5 of this study presents low ELCR values $(0.89 \times$ $10^{-3}$ to $2.89 \times 10^{-3}$ ) were reported and implied the coal mine at Okobo poses no fatal cancer risk to the Okobo populace at the time of this study.

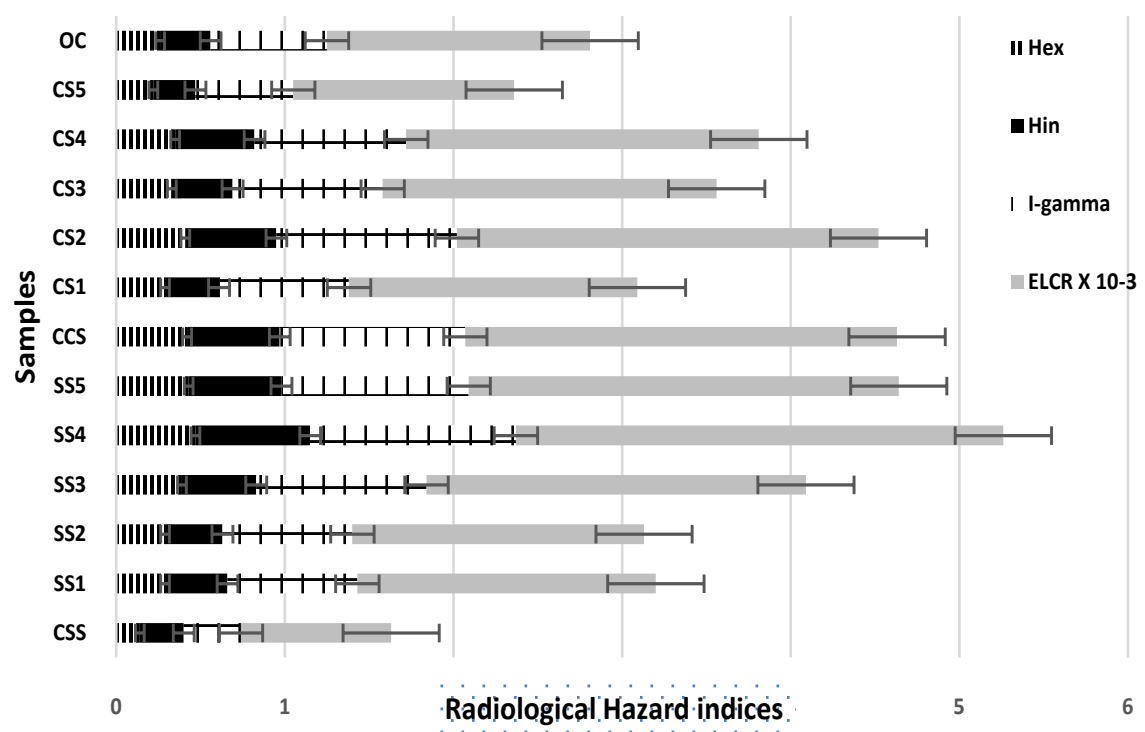

Figure 5. Radiological detriments of coal, soil and plant samples from Okobo coal mine site. 


\subsubsection{Absorbed Gamma Dose Rate (D)}

This is a measure of the energy deposited in a medium by ionizing radiation. In the SI system of units, the unit of measure is joules per kilogram, and its special name is gray (Gy). Absorbed dose is used in the calculation of dose uptake in living tissue in both radiation protection and radiology. It is also used to directly compare the effect of radiation on inanimate matter.

The measured activity concentrations of ${ }^{226} \mathrm{Ra},{ }^{232} \mathrm{Th}$ and ${ }^{40} \mathrm{~K}$ were converted into doses by applying the conversion factors $0.462,0.604$ and 0.0417 for uranium, thorium and potassium, respectively. These factors were used to calculate the total dose rate $\left(\mathrm{nGy} \cdot \mathrm{h}^{-1}\right)$ using the following equation:

$$
D=0.462 A_{\mathrm{Ra}}+0.604 A_{\mathrm{Th}}+0.0417 A_{\mathrm{K}}
$$

where, $A_{\mathrm{Ra}}, A_{\mathrm{Th}}$ and $A_{\mathrm{K}}$ has been previously defined. In this study, absorbed gamma dose rate deduced for the cassava sample is in the range of 36.04 to 69.68 $\mathrm{nGy} \cdot \mathrm{h}^{-1}$, with the control sample having the highest value.

\subsubsection{Annual Effective Dose (AED)}

The annual effective dose rate outdoors in units of ( $\mu \mathrm{Sv}$ /year) was calculated by the following formula:

$$
\text { AED }=\text { Absorbed dose }\left(\mathrm{nGy} \cdot \mathrm{h}^{-1}\right) \times 8760 \mathrm{~h} \times 0.7 \mathrm{~Sv} \cdot \mathrm{Gy} / \text { year } \times 0.2 \times 10^{-3}
$$

From Table 9, the AED values for the cassava samples vary from 44.20 - 85.46 $\mu \mathrm{Sv}$ /year. Some values for cassava sample (CCS, CS2 and CS4) were above the world average values at $70 \mathrm{mSv} /$ year as observed (Diab, 2008). This calls for concern in some samples. On a mild note, an average of $68.098 \mathrm{mSv} / \mathrm{year}$ which poses no threat is more generalized for the cassava samples within Okobo coal field region.

Generally, the calculated values for $R a_{e q}$, external hazard index; $H_{e x}$ internal hazard index and the $H_{i n}$ values for Okobo coal sample itself were $96.94 \mathrm{~Bq} \cdot \mathrm{kg}^{-1}$, 0.26 and 0.30 , respectively. These values were below the safety limits stipulated by UNSCEAR (2000). These implied that radioactivity of Okobo coal is non-hazardous and within safe limits. Similarly, the calculated mean values (Figure 6) for

Table 9. Absorbed gamma dose (D) and annual effective dose (AED) on cassava samples from Okobo mine site.

\begin{tabular}{ccccccc}
\hline \multirow{2}{*}{ S/No } & Cassava & \multicolumn{3}{c}{ Radionuclides } & \multicolumn{2}{c}{ Adsorbed Doses } \\
\cline { 3 - 7 } & Sample & K-40 & Ra-226 & Th-232 & D (nGy.h $\left.{ }^{-1}\right)$ & AED $(\mu$ Sv/year) \\
\hline 1 & CCS & 232.26 & 50.23 & 60.91 & 69.68 & 85.46 \\
2 & CS 1 & 113.96 & 9.03 & 63.85 & 47.49 & 58.24 \\
3 & CS 2 & 289.32 & 48.11 & 55.79 & 67.99 & 83.38 \\
4 & CS 3 & 258.54 & 8.39 & 66.49 & 54.82 & 67.28 \\
5 & CS 4 & 103.55 & 45.58 & 52.53 & 57.10 & 70.03 \\
6 & CS 5 & 184.53 & 14.26 & 36.02 & 36.04 & 44.20 \\
\hline
\end{tabular}




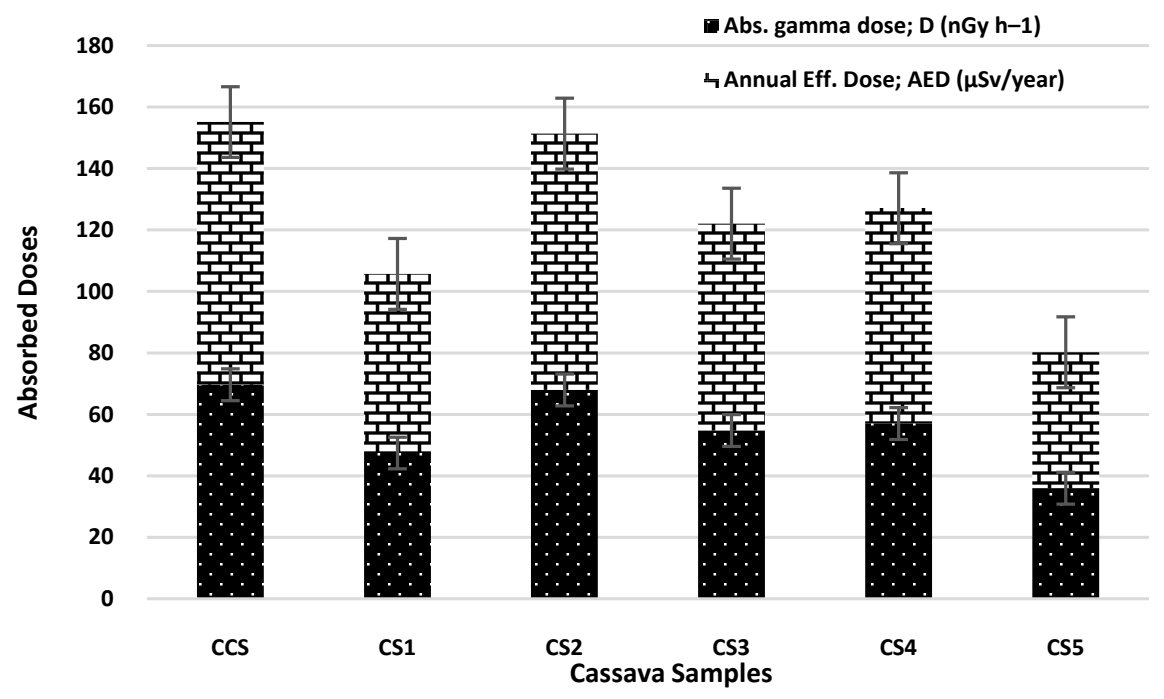

Figure 6. Absorbed gamma dose (D) and annual effective dose (AED) of cassava samples from Okobo mine site.

Radium equivalent activity $\left(R a_{e q}\right)$, External hazard index $\left(H_{e x}\right)$ and internal hazard index $\left(H_{\text {in }}\right)$, for the Okobo Soil Sample, Control Soil Sample, Okobo Harmonised Cassava Sample, Control Cassava Sample Okobo, were all within the desired safe limits of less than $370 \mathrm{~Bq} \cdot \mathrm{Kg}^{-1}$ (for $R a_{e q}$ ), less than unity (for $H_{e x} H_{i n \text {, }}$ and $I_{\gamma r}$ ) and below 0.05 for ELCR. Thus, none of these samples pose any radiation risk. On the contrary, Representative gamma index $\left(I_{\gamma r}\right)$ and AEDE values for some samples calls for continual radiological impact monitoring.

\section{Conclusion}

The natural radiological activity concentrations of coal, cassava, water and soil samples within Okobo coal field have been estimated by gamma spectrometry. Radiological detriment and hazard indices values for $R a_{e q}$ external hazard index $H_{e x}$ internal hazard index $H_{i n}, I_{\gamma r}$ and the ELCR for Okobo coal and neighbouring environmental samples were below the safety limits stipulated by UNSCEAR. This implied that radioactivity of Okobo coal is non-hazardous and within safe limits for now. Exceptions to this generalization are representative gamma index $\left(I_{\gamma r}\right)$ and annual effective dose equivalent values for some samples, requiring continual radiological impact monitoring.

\section{Conflicts of Interest}

The authors declare no conflicts of interest regarding the publication of this paper.

\section{References}

Adeniji, A. O., Okoh, O. O., \& Okoh, A. I. (2019). Levels of Polycyclic Aromatic Hydrocarbons in the Water and Sediment of Buffalo River Estuary, South Africa and Their Health Risk Assessment. Archives of Environmental Contamination and Toxicology, 76, 657-669. https://doi.org/10.1007/s00244-019-00617-w 
Alashrah, S., \& Taher, A. E. (2017). Elemental Analysis and Radiation Hazards Parameters of Bauxite Located in Saudi Arabia. Journal of Physics: Conference Series, 817, 1-7. https://doi.org/10.1088/1742-6596/817/1/012061

Alausa, S. K., Akanmu, I. O., Odunaike, K., Adeyeloja, A., \& Olabamiji, A. O. (2019). Radiological Impact Assessment of Soil Matrices from Saje and Ilaro Dumpsites in Southwestern Nigeria. FTST), 4, 805-809.

Bachama, Y. D., Ahmed, A. L., Lawal, K. M., \& Arabi, A. S. (2017). Assessment of Radiological Detriments in Rock Samples from South West of the Kerri-Kerri Formation Upper Benue Trough, Northeast Nigeria. FTSTJ, 2, 118-121.

Bello, I. A., Jibiri, N. N., \& Momoh, H. A. (2014). Determination of External and Internal Hazard Indices from Naturally Occurring Radionuclide in Rock, Sediment and Building Samples Collected from Sikiti, Southwestern Nigeria. Journal of Natural Sciences Research, 4, 744-781.

Beretka, J., \& Mathew, P. J. (1985). Natural Radioactivity of Australian Building Materials, Industrial Wastes and Byproducts. Health, 48, 87-95.

https://doi.org/10.1097/00004032-198501000-00007

Bergh, J., Falcon, R., \& Falcon, L. (2011). Trace Element Concentration Reduction by Beneficiation of Witbank Coalfield No. 4 Seam. Fuel Process Technology, 92, 812-816. https://doi.org/10.1016/j.fuproc.2010.09.035

Diab, H. N. T. (2008). Evaluation of Natural Radioactivity in a Cultivated Area around a Fertilizer Factory. Nuclear Radiation Physics, 3, 53-62.

Din, S. A. M., Yahya, N. N. N., \& Abdullah, A. (2013). Fine Particulates Matter (PM 2.5) from Coal-Fired Power Plant in Manjung and Its Health Impacts. Procedia-Socio and Behavioral Science, 85, 92-99. https://doi.org/10.1016/j.sbspro.2013.08.341

Gawlik, B., \& Bidoglio, G. (2006). Background Values in European Soils and Sewage Sludges, Joint Research Centre (European Commission) (12 p.).

Huang, Y. J., Chen, C. F., Huang, Y. C., Yue, Q. J., Zhong, C. M., \& Tan, C. J. (2015). Natural Radioactivity and Radiological Hazards Assessment of Bone-Coal from a Vanadium Mine in Central China. Radiation Physics and Chemistry, 107, 82-88. https://doi.org/10.1016/j.radphyschem.2014.10.001

Ikwuagwu, C. S. (2017). Environmental and Health Implications of Coal Mining at Maiganga, Gombe State, Nigeria. Journal of Environment Pollution and Human Health, 5, 5-14.

Itodo, A. U., Eneji, I. S., Wuana, R. A., \& Edimeh, P. O. (2020). Contribution of Coal to the Bioavailability of PAHs in Environmental Samples. Sumerianz Journal of Scientific Research. (In Press)

Jibiri, N. N., \& Okeyode, I. C. (2012). Evaluation of Radiological Hazards in the Sediments of Ogun River, South-Western Nigeria. Radiation Physics and Chemistry, 81, 103-112. https://doi.org/10.1016/j.radphyschem.2011.10.002

Llori, A. O., \& Alausa, S. K. (2019). Estimation of Natural Radionuclides in Grasses, Soils and Cattle-Dungs from a Cattle Rearing-Field at Mangoro-Agege, Lagos State. FTST), 4, 18-24.

Lu, X., Jia, X., \& Wang, F. (2006). Natural Radioactivity of Coal and Its By-Products in the Baoji Coal-Fired Power Plant, China. Current Science, 91, 1508-1511.

Lu, X., Li, L. Y., Wang, F., Wang, L., \& Zhang, X. (2012). Radiological Hazards of Coal and Ash Samples Collected from Xi'an Coal-Fired Power Plants of China. Environmental Earth Sciences, 66, 1925-1932. https://doi.org/10.1007/s12665-011-1417-x

Manigandan, P. K., \& Chandar Shekar, B. (2014). Evaluation of Radionuclides in the Terrestrial Environment of Western Ghats. Journal of Radiation Research and Applied Sciences, 7, 310-316. https://doi.org/10.1016/j.jrras.2014.04.001 
Mujahid, M., \& Hussain, R. (2011). Measurement of Natural Radioactivity from Soil Samples of Sind, Pakistan. Radiation Protection Dosimetry, 145, 351-355. https://doi.org/10.1093/rpd/ncq423

Odunayo, A. R., Omoniyi, P., Leslie, P., \& Olorunfemi, O. (2016). Comparative Chemical and Trace Element Composition of Coal Samples from Nigeria and South Africa. American Journal of Innovative Research and Applied Sciences, 2, 391-404.

Oni, S. O. (2019). Characterization of Ash Content, Coking Tendencies and Evaluation of Physicochemical Properties of Petroleum and Coal. Petroleum and Coal, 59, 397-411.

Querol, X., Juan, R., Lopez-Soler, A., Fernandez-Turiel, J., \& Ruiz, C. R. (1996). Mobility of Trace Elements from Coal and Combustion Wastes. Fuel, 75, 821-838. https://doi.org/10.1016/0016-2361(96)00027-0

Rajesh, P., Joseph, S. V., Ramasamy, V., \& Meenakshisundaram, V. (2013). Measurement of Level of Natural Gamma Emitting Radionuclides in Charnockite Rocks of Kalrayan Hills, India. Archives of Applied Science Research, 5, 278-286.

Ravisankar, R., Vanasundari, K., Suganya, M., Raghu, Y., Rajalakshmi, A., Chandrasekaran, A., Sivakumar, S., Chandramohan, J., Vijayagopal, P., \& Venkatraman, B. (2014). Multivariate Statistical Analysis of Radiological Data of Building Materials Used in Tiruvannamalai, Tamilnadu, India. Applied Radiation and Isotopes, 85, 114-127. https://doi.org/10.1016/j.apradiso.2013.12.005

Raymond, A., Darko, E. O., \& Cyril, S. (2013). Preliminary Study on the Levels of Natural Radionuclides in Sediments of the Tono Irrigation Dam, Navrongo. The International Journal of Science \& Technoledge, 2, 770-773.

Sambo, A. S., Garba, B., Zarma, I. H., \& Gaji, M. M. (2012). Electricity Generation and the Present Challenges in the Nigerian Power Sector. Journal of Energy and Power Engineering, 6, 1050-1059.

http://luiscabareda.com/doc2011/JOURNAL_ENERGY_POWER_ENGINEERING_JU LIO_2012.pdf

Taskin, H., Karavus, M., Ay, P., Topuzoglu, A., Hidiroglu, S., \& Karahan, G. (2009). Radionuclide Concentrations in Soil and Lifetime Cancer Risk Due to Gamma Radioactivity in Kirklareli, Turkey. Journal of Environmental Radioactivity, 100, 49-53. https://doi.org/10.1016/j.jenvrad.2008.10.012

UNSCEAR (1982). Ionizing Radiation Sources and Biological Effects (pp. 1-43). Report to the General Assembly, with Annexes, New York: United Nations.

UNSCEAR (2000). United Nations Scientific Committee on the Effects of Atomic Radiation. Sources and Effects of Ionizing Radiation (Volume I). New York: United Nations. https://www.unscear.org/unscear/en/publications/2000_1.html

Usikalu, M. R., Rabiu, A. B., Oyeyemi, K. D., Achuka, J. A., \& Maaza, M. (2017). Radiation Hazard in Soil from Ajaokuta North-Central Nigeria. International Journal of Radiation Research, 15, 219-224. https://doi.org/10.18869/acadpub.ijrr.15.2.219 